\title{
DAMPAK TEKNOLOGI INFORMASI DAN PEMAHAMAN SISTEM INFORMASI AKUNTANSI TERHADAP KINERJA PENGELOLAAN KEUANGAN PEMERINTAH
}

\author{
Marwah Yusuf \\ Sekolah Tinggi Ilmu Ekonomi Makassar Bongaya \\ Email : marwah_yusuf@gmail.com
}

\begin{abstract}
Abstrak
Penelitian ini bertujuan untuk menguji dan menganalisis pengaruh Teknologi Informasi dan Pemahaman Sistem Informasi terhadap Kinerja Pengelolaan Keuangan Pemerintah pada Satuan Kerja Perangkat Daerah yang ada di Pemerintahan Kota Makassar. Teknik penentuan sampel menggunakan metode purposive sampling dengan menentukan kriteria-kriteria tertentu sehingga jumlah sampel adalah 75 responden yang mewakili 3 responden dari 25 OPD di Kota Makassar. Data dikumpulkan melalui hasil kuesioner yang dibagikan kepada responden. Data yang dikumpulkan diuji dengan uji instrument (uji validitas dan uji reabilitas), uji asumsi klasik (uji normalitas dan uji heteroskedastisitas), dan dianalisis menggunakan metode analisis deskriptif dan analisis inferensial. Pengujian hipotesis penelitian dilakukan dengan (uji parsial, uji statistik F, dan uji koefisien determinasi.) Hasil penelitian ini menemukan pengaruh berpengaruh positif dan signifikan antara Teknologi Informasi, Pemahaman Sistem Informasi Akuntansi dan Teknologi Informasi dan Pemahaman Sistem Informasi Akuntansi berpengaruh positif dan signifikan secara simultan terhadap Kinerja Pengelola Keuangan Pemerintah.
\end{abstract}

Keywords: Kinerja Pengelolaan Keuangan Pemerintah, Pemahaman Sistem Informasi akuntansi, dan Teknologi Informasi.

\begin{abstract}
Abstrack
This study aims to examine and analyze the effect of Information Technology and Information Systems Understanding on Government Financial Management's Performance at Regional Work Units in Makassar City Government. The sampling technique used the purposive sampling method by determining specific criteria so that the number of samples was 75 respondents representing three respondents from 25 OPDs in Makassar City. Data was collected through the results of a questionnaire distributed to respondents. The data collected was tested using instrument tests (validity and reliability tests), classical assumption tests (normality tests and heteroscedasticity tests), and analyzed using descriptive analysis methods and inferential analysis. The research hypothesis testing was carried out by (partial test, $F$ statistical test, and determination coefficient test.) This study found a positive and significant effect between Information Technology, Understanding Accounting Information Systems, and Information Technology and Understanding Accounting Information Systems simultaneously positive and significant effects on Government Financial Managers' Performance.
\end{abstract}

Keyword: Government Financial Management Performance, Understanding Information Systems Accounting and Information Technology

\section{PENDAHULUAN}

Penyajian laporan keuangan yang dipublikasi oleh Pemerintah daerah ke masyarakat harus bersifat terbuka dan memiliki kebenaran yang valid sehingga para pengguna laporan keuangan dapat memahaminya (Rahim et al., 2020; Lannai \& Amin, 2020). Oleh karena itu diperlukan suatu pelaporan yang bersifat akurat, relevan, tepat waktu dan dapat dipercaya dalam rangka memuaskan kebutuhan para pengguna laporan keuangan dan dapat menciptakan otonomi daerah yang akurat sehingga dapat 
meningkatkan kinerja pengelolaan keuangan pemerintah (Erawati \& Abdulhadi, 2018). Berdasarkan hal tersebut, sebuah laporan keuangan membutuhkan informasi yang tentunya juga berkualitas dan akurat (Yusuf \& Kanji, 2020). Menurut Sari \& Pamono, (2013), informasi yang berkualitas tentunya diperoleh dari adanya teknologi informasi yang dirancang dengan baik. Kehadiran teknologi informasi terutama dalam dunia bisnis banyak dimanfaatkan oleh para pelaku bisnis untuk memperoleh keuntungan baik yang bersifat material maupun non-material karena efisiensi dan pengendalian internal yang baik dapat tercipta dalam kegiatan organisasi bisnis. Wardani et al., (2017) menyatakan bahwa teknologi informasi mempunyai kelebihan dalam keakuratan dan ketepatan hasil operasi datanya. Pemanfaatan teknologi informasi juga akan mengurangi kesalahan yang terjadi, baik yang disengaja maupun tidak disengaja. Penerapan teknologi informasi pada setiap perusahaan atau organisasi tentunya memiliki tujuan yang berbeda karena bertujuan untuk mendukung kepentingan usaha suatu organisasi.

Pada tahun 2017 ICW (Indonesia Corruption Watch) mencatat dari 576 kasus korupsi yang berhasil disidik, 26 kasus diantaranya adalah pengembangan kasus yakni adanya tersangka baru yang ditetapkan oleh penegak hukum. Salah satu kasusnya adalah pemberian Izin Pinjam Pakai Kawasan Hutan (IPPKH) serta penyalahgunaan menyangkut ekspor nikel oleh PT Kemakmuran Pertiwi Tambang yang merugikan keuangan negara sekitar Rp 630 milyar dan ditangani oleh Kejaksaan Agung. Sektor pengelolaan anggaran desa pada tahun 2017 sangat rawan dikorupsi, ada sebanyak 98 kasus korupsi yang terkait dengan anggaran desa. Selain itu, sektor pemerintahan menjadi peluang cukup besar untuk dikorupsi. Hal yang sama terjadi pada sektor pendidikan, transportasi dan sosial kemasyarakatan.

Teknologi informasi yang banyak digunakan dalam dunia bisnis adalah sistem informasi akuntansi. Perbedaan antara teknologi informasi dengan sistem informasi menurut Rafiudin, (2013), adalah sistem informasi mencakup seluruh sistem didalam perusahaan secara keseluruhan termasuk teknologi informasi, akuntansi, manajemen, dan produksi; sedangkan teknologi informasi ada untuk membantu atau menunjang kegiatan sistem informasi, diantaranya pembuatan hardware, software, network, dan database. Krismiaji, (2015) menyatakan bahwa sistem informasi akuntansi merupakan sebuah sistem yang dapat memproses data dan transaksi guna untuk menghasilkan informasi yang dapat bermanfaat untuk merencanakan, mengendalikan, serta mengoperasikan bisnis. Untuk dapat menghasilkan informasi yang diperlukan oleh para pembuat keputusan, sistem informasi akuntansi harus melaksanakan tugas-tugas seperti mengumpulkan transaksi dan data lain dan memasukannya ke dalam sistem, memeproses data transaksi, menyimpan data untuk keperluan di masa mendatang, menghasilkan informasi yang diperlukan dengan memproses laporan atau memungkinkan para pemakai untuk melihat sendiri data yang tersimpan di komputer, mengendalikan seluruh proses sedemikian rupa sehingga informasi yang dihasilkan akurat dan dapat dipercaya. Romney \& Steinbart, (2014) mengemukakan bahwa salah satu komponen dalam sistem informasi akuntansi adalah sumber daya manusia. Agar sistem informasi dapat dijalankan dengan maksimal, maka dibutuhkan kemampuan dari sumber daya manusia untuk mengoperasikannya. Oleh karena itu, pemahaman terhadap sistem informasi khususnya terkait akuntansi sangat diperlukan untuk menghasilkan output yang akurat, relevan dan tepat waktu.

Keberadaan sebuah sistem akuntansi menjadi sangat penting karena fungsinya dalam menetukan kualitas (kinerja) informasi pada laporan keuangan. Kinerja 
pengelolaan keuangan menjadi gambaran mengenai tingkat pencapaian dalam pelaksanaan kegiatan pengelolaan kuangan dalammewujudkan sasaran, tujuan, visi dan misi organisasi yang tertuang dalam strategi perencanaan suatu organisasi. Menurut PP Nomor 58 Tahun 2005, kinerja adalah keluaran/hasil dari kegiatan/program yang akan atau telah dicapai sehubungan dengan pengguna anggaran dengan kuantitas yang diukur. Selain itu kinerja suatu organisasi dapat dilihat dari tingkatan sejauh mana organisasi dapat mencapai tujuan yang sudah ditetapkan sebelumnya. Dengan demikian, kinerja pengelola keuangan daerah adalah suatu hasil yang dicapai, prestasi yang diperlihatkan, kemampuan kerja aparatur/pegawai pengelola keuangan daerah dalam melaksanakan tugas sesuai dengan standar atau persyaratan yang telah ditentukan sebelumnya seperti aturan perundangan-undangan dan aturan lainnya dalam pengelolaan keuangan daerah. Kinerja (prestasi kerja) pengelola keuangan daerah adalah hasil kerja secara kualitas dan kuantitas yang dicapai oleh seorang aparatur/pegawai pengelola keuangan daerah dalam melaksanakan tugasnya, sesuai dengan tanggungjawab yang diberikan kepadanya.

Untuk melahirkan kinerja pengelolaan keuangan yang baik, dibutuhkan informasi keuangan berkualitas yang berasal dari sistem informasi akuntansi. PERMENDAGRI No. 21 Tahun 2011 tentang Pedoman Pengelolaan Keuangan Daerah menyatakan bahwa sistem informasi akuntansi keuangan pemerintah daerah meliputi serangkaian prosedur mulai dari proses pengumpulan data, pencatatan, pengihtisaran, sampai dengan pelaporan keuangan dalam rangka pertanggungjawaban pelaksanaan APBN yang dapat dilakukan secara manual atau menggunakan aplikasi komputer. Hal tersebut menunjukkan bahwa sistem informasi akuntansi khususnya yang telah diterapkan dalam pemerintahan didukung oleh pemahaman sumber daya manusia terhadap sistem informasi akuntansi seharusnya menghasilkan output yang berkualitas dan tepat waktu. Hasil observasi awal penelitian ini menunjukkan bahwa secara faktual menunjukkan hal yang berbeda pada Badan Perencanaan dan Pembangunan Daerah (BAPPEDA) Kota Makassar. Kasus keterlambatan penyetoran dokumen Rencana Kerja (Renja) dan Laporan Akuntabilitas Kinerja Pemerintah (LAKIP) tahun 2018 oleh SKPD kota Makassar. Dilansir dari laman Sulselsatu.com, Iriani Hadijah selaku Kepala Badan Perencanaan dan Pembangunan Daerah (Bappeda) Kota Makassar, menyatakan bahwa pada tanggal 31 Desember 2018 lalu seharusnya menjadi hari terakhir penyerahan dokumen tersebut. Dokumen tersebut dibutuhkan untuk membuat Rencana Kerja Pemerintah Daerah (RKPD) di tahun 2020 dan ini disusun setiap tahun sesuai yang diatur dalam UU nomor 25 tahun 2004.

Topik penelitian ini telah dikaji oleh beberapa peneliti, seperti Chintya, (2015) yang membuktikan bahwa pemanfaatan teknologi informasi memiliki pengaruh positif terhadap kinerja instansi pemerintah. Berikutnya, penelitian yang dilakukan oleh Liza et al., (2017) yang membuktikan bahwa teknologi informasi berpengaruh terhadap kualitas laporan keuangan. Adapun penelitian yang dilakukan oleh Erawati \& Abdulhadi, (2018) menunjukkan bahwa pemahaman sistem akuntansi keuangan pemerintah daerah tidak berpengaruh signifikan terhadap kualitas informasi laporan keuangan pemerintah daerah dan utilitas teknologi dipengaruhi secara positif terhadap kualitas laporan keuangan pemerintah daerah. informasi. Selanjutnya, penelitian yang dilakukan oleh Diana et al., (2017) yang membuktikan bahwa sistem akuntansi berpengaruh signifikan terhadap Kinerja Pemerintah Daerah. Penelitian ini berbeda dengan penelitian-penelitian yang dilakukan oleh para peneliti tersebut. Perbedaan tersebut terletak pada subjek penelitian 
yang dimana penelitian ini merujuk pada Satuan Kerja Perangkat Daerah yang ada di Pemerintahan Kota Makassar. Secara objektif, penelitian kami untuk menguji dan menganalisis pengaruh Teknologi Informasi dan Pemahaman Sistem Informasi terhadap Kinerja Pengelolaan Keuangan Pemerintah pada Satuan Kerja Perangkat Daerah yang ada di Pemerintahan Kota Makassar.

Teori Keagenan (Agency Theory) merupakan model keagenan yang dirancang menjadi sebuah sistem yang melibatkan kedua belah pihak yaitu manajemen dan pemilik. Selanjutnya, manajemen dan pemilik melakukan kesepakatan (contract) kerja untuk mencapai manfaat (utility) yang diharapkan. (Wahyu, 2016) menyatakan bahwa kerangka hubungan prinsipal agen merupakan suatu pendekatan yang sangat penting untuk menganalisis komitmen-komitmen kebijakan publik. Pada sektor publik, hubungan keagenan yang terjadi adalah hubungan antara masyarakat dengan pemerintah atau hubungan antara pemerintah daerah dengan pemerintah pusat. Pemerintah pusat memberikan wewenang terhadap pemerintah daerah pemerintah daerah juga harus mempertanggung jawabkan tugasnya terhadap pemerintah pusat. Disisi lain pemerintah dearah juga harus memaksimalkan kesejahteraan mereka (Zelmiyanti, 2016). Hubungan keagenan terlihat jelas saat penyusunan anggaran. Pemerintah daerah disini provinsi menyusun anggaran kemudian anggaran tersebut diserahkan kepusat setelah adanya pengesahan dari pusat pemerintah daerah menjalankan kegiatan berdasarkan anggaran tadi. Akhirnya pemerintah daerah harus mempertanggung jawabkan realisasi anggaran terhadap pemerintah pusat. Untuk meminimalisir risiko, dibutuhkan adanya pendekatan yang dapat meningkatkan penyusunan Laporan Akuntabilitas Kinerja Instansi Pemerintah untuk dapat menganalisis komitmen-komitmen kebijakan publik. Pihak manajemen instansi harus melakukan kesepakatan dengan pegawai yang memiliki keahlian pada bidang tersebut. Maka dalam meningkatkan kepentingan publik yang dilandasi dari segi kinerja pengelola keuangan pemerintah, dibutuhkan pegawai yang ahli dalam memahami teknologi informasi dan sistem informasi.

Kinerja keuangan pemerintah daerah merupakan keluaran atau hasil dari kegiatan atau program yang akan atau telah dicapai sehubungan dengan penggunaan anggaran daerah dengan kuantitas dan kualitas yang terukur. Kasmir, (2013) menyatakan dalam pengertian yang sederhana, Kinerja pengelolaan keuangan adalah laporan yang menunjukkan kondisi keuangan perusahaan pada saat ini atau dalam suatu periode tertentu. Selanjutnya menurut Mahsun, (2013) indikator kinerja keuangan pemerintah daerah yaitu masukan, proses, keluaran, hasil, manfaat, dan impact. Sehingga dibutuhkan adanya teknologi informasi dan pemahaman sistem informasi akuntansi agar dapat meningkatkan kinerja pengelolaan keuangan pemerintah. Menurut Williams \& Sawyer, (2011) teknologi informasi merupakan suatu teknologi yang menggabungkan komputasi (komputer) dengan jalur komunikasi yang mempunyai kecepatan tinggi membawa data, suara, dan video. Hal yang sama juga di ungkapkan oleh Prasajo, (2011) teknologi informasi diartikan sebagai ilmu pengetahuan dalam bidang informasi yang berbasis komputer dan perkembanganya sangat pesat. Uno \& Lamatenggo, (2011) juga mengemukakan teknologi informasi adalah suatu teknologi yang digunakan untuk mengolah data. Wahyudi, (2010) menyatakan bahwa pemanfaatan teknologi informasi yang baik secara garis besar dapat memberikan dampak yang positif bagi pengelolaan keuangan pemerintah daerah. Teknologi informasi mempunyai kelebihan dalam keakuratan dan ketepatan hasil operasi datanya. Pemanfaatan teknologi informasi juga akan mengurangi kesalahan yang terjadi, baik yang disengaja maupun tidak disengaja 
(Wardani et al., 2017). Sutarman, (2012) menyatakan bahwa Teknologi informasi dapat di ukur dengan beberapa indikator yaitu mengolah (processing), menghasilkan (generating), menyimpan (storage), mencari kembali (retrieval), dan transmisi (transmission).

Penelitian ini telah dikaji oleh beberapa peneliti, diantaranya yaitu Chintya, (2015) yang membuktikan dalam hasil penelitiannya bahwa pemanfaatan teknologi informasi memiliki pengaruh positif terhadap kinerja instansi pemerintah. Selanjutnya, penelitian yang dilakukan oleh Liza et al., (2017) yang membuktikan bahwa teknologi informasi berpengaruh terhadap kualitas laporan keuangan. Berdasarkan hal tersebut, maka hipotesis pertama pada penelitian ini adalah:

$\mathrm{H}_{1}$ : Teknologi informasi berpengaruh positif dan signifikan terhadap kinerja pengelola keuangan pemerintah

Keberadaan sistem informasi sangat dibutuhkan untuk meningkatkan kinerja pengelolaan keuangan karena fungsinya dalam menetukan kualitas (kinerja) informasi laporan keuangan. Untuk menghasilkan informasi yang diperlukan oleh para pembuat keputusan, sistem informasi akuntansi harus melaksanakan fungsi akuntansi secara komperehensif untuk keperluan di masa mendatang sehingga menghasilkan informasi yang berkualitas dan dapat digunakan oleh para stakeholders dalam pengambilan keputusan (Krismiaji, 2015). Pemahaman terhadap sistem informasi akuntansi sangat diperlukan. karena kemampuan seseorang untuk menjalankan sebuah sistem yang dapat memproses data dan transaksi guna untuk menghasilkan informasi yang dapat bermanfaat untuk merencanakan, mengendalikan, serta Menurut Susanto, (2017), indikator yang dapat mengukur pemahaman sistem informasi akuntansi, yaitu pengetahuan, kemampuan, dan keahlian

Erawati \& Abdulhadi, (2018) dalam penelitiannya membuktikan bahwa pemahaman sistem akuntansi keuangan pemerintah daerah tidak berpengaruh signifikan terhadap kualitas informasi laporan keuangan pemerintah daerah dan utilitas teknologi dipengaruhi secara positif terhadap kualitas laporan keuangan pemerintah daerah. informasi. Sedangkan Diana et al., (2017) dalam penelitiannya membuktikan bahwa sistem informasi akuntansi berpengaruh signifikan terhadap kinerja pemerintah daerah. Perbedaan penelitian ini dengan penelitan terdahulu terletak pada tempat penelitian yang dimana penelitian ini dilakukan pada Satuan Kerja Perangkat Daerah yang ada di Pemkot Makassar. Berdasarkan penjelasan tersebut, maka hipotesis kedua pada penelitian ini adalah:

$\mathrm{H}_{2}$ : Pemahaman sistem informasi Akuntansi berpengaruh positif dan signifikan terhadap kinerja Pengelola Keuangan Pemerintah

Menurut Sutarman, (2012), tujuan dari adanya teknologi informasi adalah untuk memecahkan masalah, membuka kreativitas, dan meningkatkan efektivitas dan efesiensi dalam melakukan pekerjaan. Teknologi informasi digunakan untuk mengolah data termasuk memproses, mendapatkan, menyusun, menyimpan, memanipulasi data dalam berbagai cara untuk menghasilkan informasi yang berkualitas, relevan, akurat, dan tepat waktu sehingga dapat digunakan dalam penyusunan Laporan Akuntabilitas Kinerja Instansi Pemerintah (Maflikhah, 2010). Selain itu, pemahaman terhadap sistem informasi merupakan hal yang perlu dicermati. Menurut Mukmin \& Abdullah, (2015), Penyajian informasi seperti informasi keuangan yang memadai harus dilakukan oleh 
personel yang memiliki pemahaman sistem informasi akuntansi. Chintya, (2015) membuktikan bahwa teknologi informasi dan pemahaman sistem informasi akuntansi berpengaruh positif dan signifikan secara simultan terhadap kinerja pengelola keuangan pemerintah. Berdasarkan penjelasan tersebut, maka hipotesis ketiga pada penelitian ini adalah:

$\mathrm{H}_{3}$ : Teknologi informasi dan Pemahaman sistem informasi Akuntansi berpengaruh positif dan signifikan secara simultan terhadap kinerja Pengelola Keuangan Pemerintah

Berdasarkan hal tersebut, maka kerangka konseptual pada penelitian ini dapat dijelaskan pada gambar berikut:

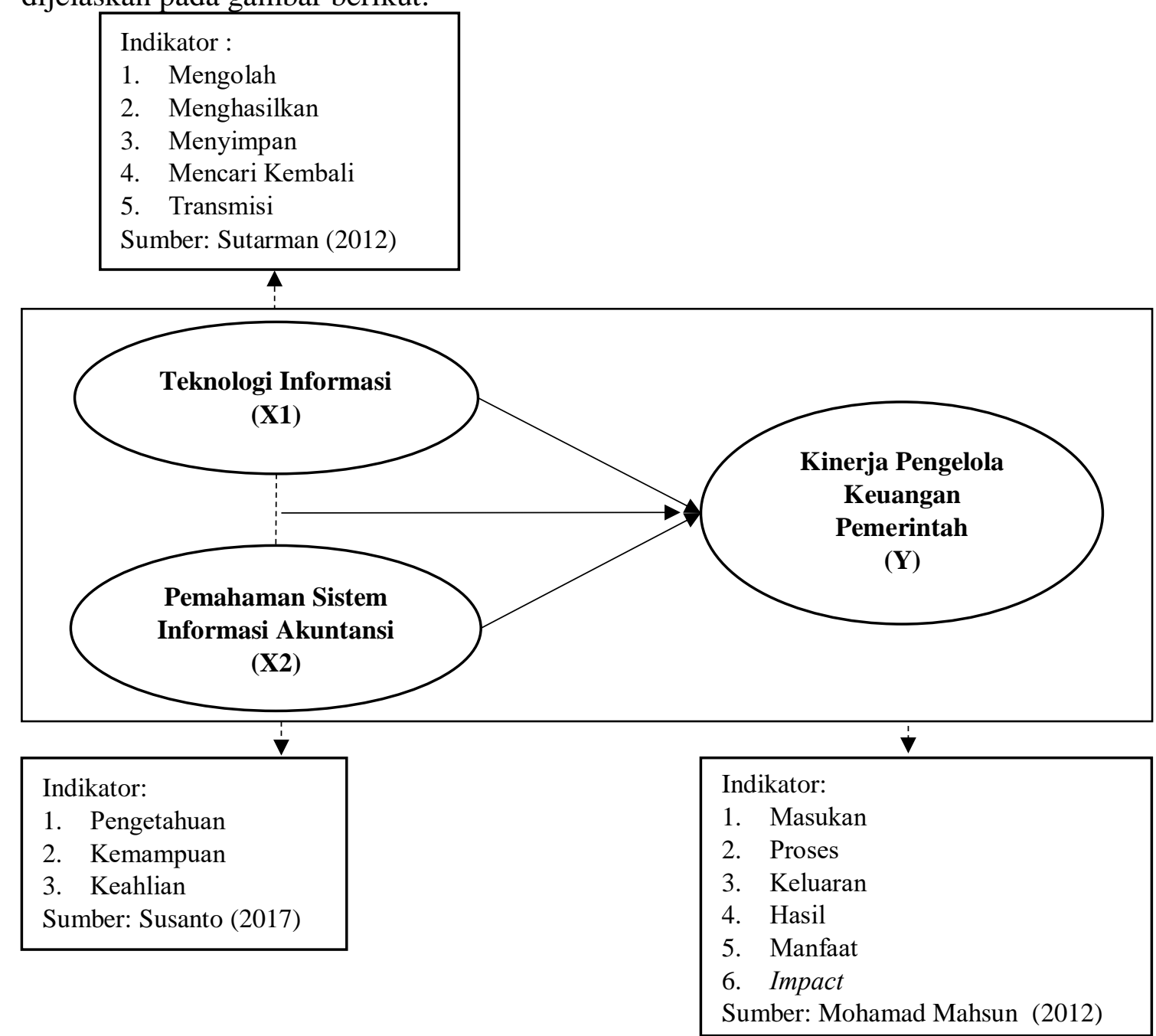

Gambar 1. Kerangka Konseptual

\section{METODE PENELITIAN}

Penelitian ini merupakan penelitian kuantitatif yang dilaksanakan di SKPD dinas kota Makassar. Populasi dalam penelitian ini yaitu sebanyak 55 SKPD di kota Makassar dengan jumlah sampel 75 responden yang mewakili 3 responden dari 25 OPD. Data penelitian kami peroleh melalui kuesioner yang dibagikan kepada responden. Data yang 
Hal. 55 - 70

e-ISSN : 2621-4377 \& p-ISSN : 1829-8524

Hbmepage: https//e-jurnal.stiendbel-indonesiaacid/indexphp/akmen

dikumpulkan akan diuji dengan uji instrument (uji validitas dan uji reabilitas), uji asumsi klasik (uji normalitas dan uji heteroskedastisitas), dan dianalisis menggunakan metode analisis deskriptif dan analisis inferensial. Terakhir, akan dilakukan uji hipotesis, yaitu uji parsial, uji statistik F, dan uji koefisien determinasi. Adapun definisi operasional variabel dalam tabel 1 .

Tabel 1. Operasional Variabel

\begin{tabular}{|c|c|c|c|}
\hline No & Variabel & Indikator & Skala \\
\hline 1. & Teknologi Informasi $\left(\mathrm{X}_{1}\right)$ & $\begin{array}{l}\text { 1. } \text { Mengolah } \\
\text { 2. Menghasilkan } \\
\text { 3. Menyimpan } \\
\text { 4. Mencari Kembali } \\
\text { 5. Transmisi } \\
\text { Sumber: (Sutarman, 2012) }\end{array}$ & Ordinal \\
\hline 2. & $\begin{array}{l}\text { Pemahaman Sistem Informasi } \\
\text { Akuntansi }\left(\mathrm{X}_{2}\right)\end{array}$ & $\begin{array}{l}\text { 1. Pengetahuan } \\
\text { 2. Kemampuan } \\
\text { 3. Keahlian } \\
\text { Sumber: (Susanto, 2017) }\end{array}$ & Ordinal \\
\hline 3. & $\begin{array}{l}\text { Kinerja Pengelola Keuangan } \\
\text { Pemerintah (Y) }\end{array}$ & $\begin{array}{l}\text { 1. Masukan } \\
\text { 2. Proses } \\
\text { 3. Keluaran } \\
\text { 4. Hasil } \\
\text { 5. manfaat } \\
\text { 6. Impact } \\
\text { Sumber: (Mahsun, 2013) }\end{array}$ & Ordinal \\
\hline
\end{tabular}

Source: Data diolah (2020)

\section{HASIL PENELITIAN}

Tabel 2. Rincian Penyebaran Kuesioner

\begin{tabular}{clcc}
\hline No & & Kumlah & Persentase \\
\hline 1 & Distribusi Kuesioner & 75 & $100 \%$ \\
2 & Kuesioner kembali & 54 & $72 \%$ \\
3 & Kuesioner yang cacat/tidak dapat diolah/tidak terisi & 21 & $28 \%$ \\
4 & Kuesioner yang dapat diolah & 54 & $72 \%$ \\
Sampel yang kembali $=54$ & & \\
Responden Rate $=54 / 75 \times 100 \%=72 \%$ & & \\
\hline
\end{tabular}

Source: Data diolah (2020)

Tabel 3. Tanggapan Responden terhadap Teknologi Informasi

\begin{tabular}{cccccccccc}
\hline ITEM & & STS(1) & TS(2) & N(3) & S(4) & SS(5) & N & $\begin{array}{c}\text { TOTAL } \\
\text { SKOR }\end{array}$ & Mean \\
\hline $\mathrm{X} 1.1$ & $\mathrm{~F}$ & 0 & 2 & 4 & 31 & 17 & 54 & 225 & 4.17 \\
& $\%$ & 0.0 & 3.7 & 7.4 & 57.4 & 31.5 & & & \\
$\mathrm{X} 1.2$ & $\mathrm{~F}$ & 0 & 2 & 11 & 27 & 14 & 54 & 215 & 3.98 \\
& $\%$ & 0.0 & 3.7 & 20.4 & 50.0 & 25.9 & & & \\
$\mathrm{X} 1.3$ & $\mathrm{~F}$ & 0 & 0 & 4 & 25 & 25 & 54 & 237 & 4.39 \\
& $\%$ & 0.0 & 0.0 & 7.4 & 46.3 & 46.3 & & & \\
$\mathrm{X} 1.4$ & $\mathrm{~F}$ & 0 & 2 & 4 & 31 & 17 & 54 & 225 & 4.17 \\
& $\%$ & 0.0 & 3.7 & 7.4 & 57.4 & 31.5 & & & \\
$\mathrm{X} 1.5$ & $\mathrm{~F}$ & 0 & 2 & 11 & 27 & 14 & 54 & 215 & 3.98 \\
& $\%$ & 0.0 & 3.7 & 20.4 & 50.0 & 25.9 & & & \\
$\mathrm{X} 1.6$ & $\mathrm{~F}$ & 0 & 2 & 4 & 31 & 17 & 54 & 225 & 4.17 \\
& $\%$ & 0.0 & 3.7 & 7.4 & 57.4 & 31.5 & & &
\end{tabular}


AkMen

AkMen

Hal. 55 - 70

e-ISSN : 2621-4377 \& p-ISSN : 1829-8524

Hbmepage: https//e-jurnal.stiendbel-indonesiaacid/indexphp/akmen

\begin{tabular}{cccccccccc}
\hline ITEM & STS(1) & TS(2) & N(3) & S(4) & SS(5) & N & $\begin{array}{c}\text { TOTAL } \\
\text { SKOR }\end{array}$ & Mean \\
\hline X1.7 & $\mathrm{F}$ & 0 & 2 & 11 & 27 & 14 & 54 & 215 & 3.98 \\
& $\%$ & 0.0 & 3.7 & 20.4 & 50.0 & 25.9 & & & \\
X1.8 & $\mathrm{F}$ & 0 & 0 & 4 & 25 & 25 & 54 & 237 & 4.39 \\
& $\%$ & 0.0 & 0.0 & 7.4 & 46.3 & 46.3 & & & 4.15 \\
\hline \multicolumn{7}{c}{ Total Mean } \\
\hline
\end{tabular}

Berdasarkan tabel 3, dapat disimpulkan bahwa tanggapan responden terhadap variabel Teknologi Informasi Pegawai mayoritas kebanyakan menanggapi setuju dengan total mean 4.15 serta item yang paling ditanggapi adalah item 3 dan 8 yang mengartikan bahwa pegawai menganggap teknologi menambah pengetahuan dan dapat meningkatkan kinerja pegawai.

Tabel 4. Tanggapan Responden terhadap Pemahaman Sistem Informasi Akuntansi

\begin{tabular}{cccccccccc}
\hline ITEM & STS(1) & TS(2) & N(3) & S(4) & SS $(5)$ & N & TOTAL SKOR & Mean \\
\hline X2.1 & $\mathrm{F}$ & 0 & 2 & 6 & 30 & 16 & 54 & 222 & 4.11 \\
& $\%$ & 0.0 & 3.7 & 11.1 & 55.6 & 29.6 & & & \\
$\mathrm{X} 2.2$ & $\mathrm{~F}$ & 0 & 0 & 8 & 33 & 13 & 54 & 221 & 4.09 \\
& $\%$ & 0.0 & 0.0 & 14.8 & 61.1 & 24.1 & & & \\
$\mathrm{X} 2.3$ & $\mathrm{~F}$ & 0 & 1 & 12 & 27 & 14 & 54 & 216 & 4.00 \\
& $\%$ & 0.0 & 1.9 & 22.2 & 50.0 & 25.9 & & & \\
$\mathrm{X} 2.4$ & $\mathrm{~F}$ & 0 & 2 & 6 & 29 & 17 & 54 & 223 & 4.13 \\
& $\%$ & 0.0 & 3.7 & 11.1 & 53.7 & 31.5 & & & \\
$\mathrm{X} 2.5$ & $\mathrm{~F}$ & 0 & 0 & 9 & 32 & 13 & 54 & 220 & 4.07 \\
& $\%$ & 0.0 & 0.0 & 16.7 & 59.3 & 24.1 & & & \\
$\mathrm{X} 2.6$ & $\mathrm{~F}$ & 0 & 2 & 6 & 28 & 18 & 54 & 224 & 4.15 \\
& $\%$ & 0.0 & 3.7 & 11.1 & 51.9 & 33.3 & & & \\
$\mathrm{X} 2.7$ & $\mathrm{~F}$ & 0 & 0 & 6 & 33 & 15 & 54 & 225 & 4.17 \\
& $\%$ & 0.0 & 0.0 & 11.1 & 61.1 & 27.8 & & & \\
$\mathrm{X} 2.8$ & $\mathrm{~F}$ & 0 & 1 & 12 & 28 & 13 & 54 & 215 & 3.98 \\
& $\%$ & 0.0 & 1.9 & 22.2 & 51.9 & 24.1 & & & 4.09 \\
\hline
\end{tabular}

Berdasarkan tabel 4, dapat disimpulkan bahwa tanggapan responden terhadap variabel Pemahaman Sistem Informasi Akuntansi mayoritas kebanyakan menanggapi setuju dengan total mean 4.09 serta item yang paling ditanggapi adalah item 7 yang mengartikan bahwa berkat Pemahaman Sistem Informasi Akuntansi pegawai dapat Fokus melaksanakan tugas yang berhubungan dengan akuntansi.

Tabel 5. Tanggapan Responden terhadap Kinerja Pengelola Keuangan Pemerintah

\begin{tabular}{cccccccccc}
\hline ITEM & STS(1) & TS(2) & N(3) & S(4) & SS(5) & N & $\begin{array}{c}\text { TOTAL } \\
\text { SKOR }\end{array}$ & Mean \\
\hline $\mathrm{Y} 1.1$ & $\mathrm{~F}$ & 0 & 0 & 10 & 23 & 21 & 54 & 227 & 4.20 \\
& $\%$ & 0.0 & 0.0 & 18.5 & 42.6 & 38.9 & & & \\
$\mathrm{Y} 1.2$ & $\mathrm{~F}$ & 0 & 0 & 12 & 24 & 18 & 54 & 222 & 4.11 \\
& $\%$ & 0.0 & 0.0 & 22.2 & 44.4 & 33.3 & & & \\
$\mathrm{Y} 1.3$ & $\mathrm{~F}$ & 0 & 0 & 10 & 24 & 20 & 54 & 226 & 4.19 \\
& $\%$ & 0.0 & 0.0 & 18.5 & 44.4 & 37.0 & & & \\
$\mathrm{Y} 1.4$ & $\mathrm{~F}$ & 0 & 0 & 9 & 24 & 21 & 54 & 228 & 4.22 \\
\hline
\end{tabular}




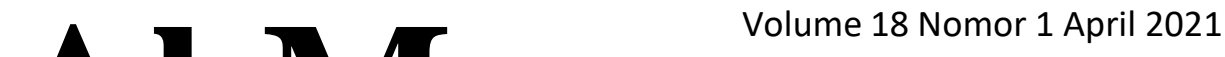

Hal. $55-70$

e-ISSN : 2621-4377 \& p-ISSN : 1829-8524

Hbmepage: https//e-jurnal.stienobel-indonesiaacid/indexphp/akmen

\begin{tabular}{cccccccccc}
\cline { 1 - 1 } & $\%$ & 0.0 & 0.0 & 16.7 & 44.4 & 38.9 & & \\
Y1.5 & $\mathrm{F}$ & 0 & 0 & 13 & 23 & 18 & 54 & 221 & 4.09 \\
& $\%$ & 0.0 & 0.0 & 24.1 & 42.6 & 33.3 & & & 4.16 \\
\hline
\end{tabular}

Source: Data diolah (2020)

Berdasarkan tabel 5, dapat disimpulkan bahwa tanggapan responden terhadap variabel Kinerja Pengelola Keuangan Pemerintah mayoritas kebanyakan menanggapi setuju dengan total mean 4.16 serta item yang paling ditanggapi adalah item 4 yang mengartikan bahwa Pegawai mampu menyelesaikan laporan keuangan tepat waktu dan sesuai dengan batas periode pelaporan yaitu per 31 desember tiap tahunnya.

Tabel 6. Hasil Uji Validitas

\begin{tabular}{ccccc}
\hline Variabel & & r hitung & r tabel & Keterangan \\
\hline Teknologi Informasi & X1.1 & 0.794 & 0,30 & Valid \\
(X1) & X1.2 & 0.805 & 0,30 & Valid \\
& X1.3 & 0.430 & 0,30 & Valid \\
& X1.4 & 0.794 & 0,30 & Valid \\
& X1.5 & 0.805 & 0,30 & Valid \\
& X1.6 & 0.794 & 0,30 & Valid \\
Pemahaman Sistem Informasi & X1.7 & 0.805 & 0,30 & Valid \\
Akuntansi & X1.8 & 0.430 & 0,30 & Valid \\
(X2) & X2.2 & 0.845 & 0,30 & Valid \\
& X2.3 & 0.658 & 0,305 & Valid \\
& X2.4 & 0.830 & 0,30 & Valid \\
& X2.5 & 0.646 & 0,30 & Valid \\
Kinerja Pengelola Keuangan & X2.6 & 0.810 & 0,30 & Valid \\
Pemerintah & X2.7 & 0.670 & 0,30 & Valid \\
(Y) & X2.8 & 0.721 & 0,30 & Valid \\
& Y1.1 & 0.843 & 0,30 & Valid \\
& Y1.2 & 0.827 & 0,30 & Valid \\
& Y1.3 & 0.782 & 0,30 & Valid \\
& Y1.4 & 0.831 & 0,30 & Valid \\
& Y1.5 & 0.841 & 0,30 & Valid \\
\hline
\end{tabular}

Source: Data diolah (2020)

Berdasarkan tabel 6, diketahui bahwa semua butir instrument variabel bebas (Teknologi Informasi dan Pemahaman Sistem Informasi Akuntansi) dan variabel terikat (Kinerja Pengelola Keuangan Pemerintah) (Y) dinyatakan valid karena $r$ hitung $>r$ tabel $(0,30)$. Berdasarkan nilai uji validitas butir instrumen seluruh variabel di atas, dapat disimpulkan bahwa data kuesioner yang peneliti gunakan dalam penelitian sudah representatif. Dalam artian mampu mengungkapkan data dengan benar.

Tabel 7. Hasil Uji Realibilitas

\begin{tabular}{cccc}
\hline Variabel & $\begin{array}{c}\text { Koefisien } \\
\text { Alpha }\end{array}$ & $\begin{array}{c}\text { Batas Nilai } \\
\text { Koefisien Alpha }\end{array}$ & Keterangan \\
\hline $\begin{array}{c}\text { Teknologi Informasi } \\
\text { (X1) }\end{array}$ & 0.865 & 0.60 & Reliabel \\
$\begin{array}{c}\text { Pemahaman Sistem } \\
\text { Informasi Akuntansi } \\
\text { (X2) }\end{array}$ & 0.881 & 0.60 & Reliabel \\
$\begin{array}{c}\text { Kinerja Pengelola Keuangan } \\
\text { Pemerintah }\end{array}$ & 0.882 & 0.60 & Reliabel \\
\hline
\end{tabular}


Berdasarkan tabel 7, diketahui bahwa semua butir instrument variabel bebas (Teknologi Informasi dan Pemahaman Sistem Informasi Akuntansi) dan variabel terikat (Kinerja Pengelola Keuangan Pemerintah) dinyatakan Reliabel karena nilai Koefisien Alpha $>0,60$. Berdasarkan nilai uji Reliabilitas butir instrumen seluruh variabel di atas, dapat disimpulkan bahwa data kuesioner yang peneliti gunakan dalam penelitian sudah terbilang handal. Dalam artian mampu mengungkapkan data dan variabel yang diteliti secara tepat.

Tabel 8. Hasil Uji Normalitas (Uji-KS)

One-Sample Kolmogorov-Smirnov Test

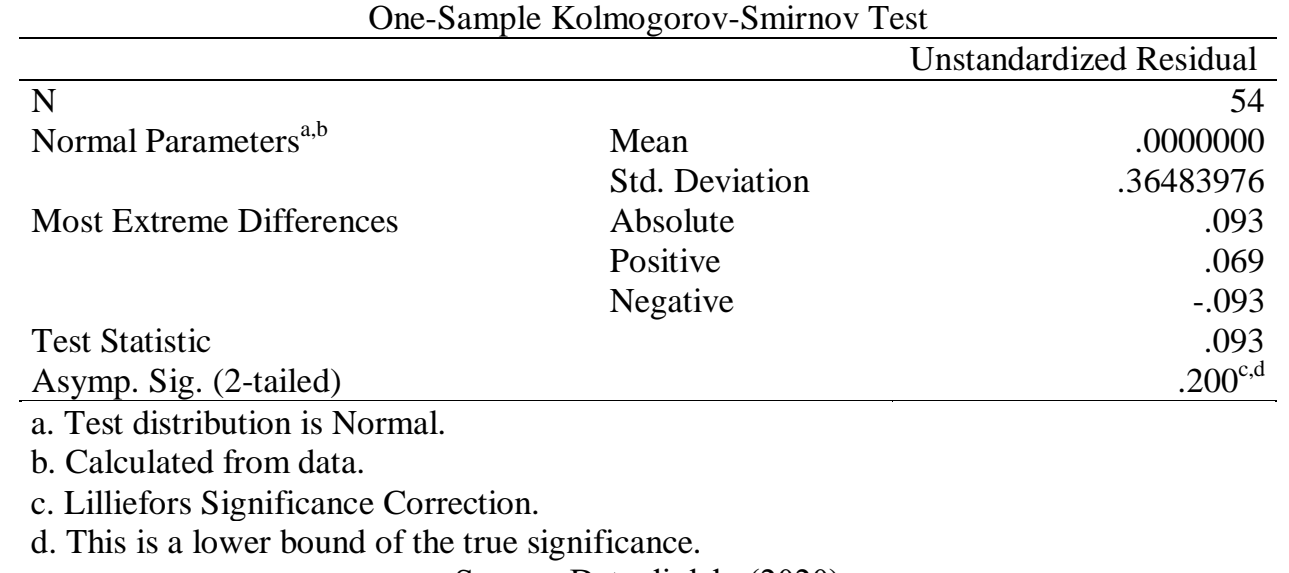

Source: Data diolah (2020)

Berdasarkan hasil SPSS 23 pada tabel 8, dapat diketahui bahwa nilai signifikansi (Asymp.sig.2-tailed) sebesar 0,200. Karena signifikansi lebih dari 0.05, maka residual terdistribusi normal.

\begin{tabular}{llc} 
Tabel 9. Hasil Uji Heterokedastisitas (Uji Glesjer) \\
& \multicolumn{2}{c}{ Moefficients ${ }^{\mathrm{a}}$} \\
\hline & \multicolumn{1}{c}{ Model } & Sig. \\
\hline 1 & (Constant) & .044 \\
& Teknologi Informasi & .081 \\
& Pemahaman Sistem Informasi Akuntansi & .476 \\
\hline
\end{tabular}

a. Dependent Variable: res_2

Source: Data diolah (2020)

Berdasarkan tabel 9, dapat diketahui bahwa nilai signifikansi pada variabel Teknologi Informasi adalah 0,081 > 0,05. Variabel Pemahaman Sistem Informasi Akuntansi adalah 0,476 > 0,05 artinya variabel Teknologi Informasi dan Pemahaman Sistem Informasi Akuntansi tidak terjadi masalah heterokedastisitas dalam model regresi.

Tabel 10. Hasil Uji Analisis Regresi Linier Berganda

\begin{tabular}{ccc}
\multicolumn{4}{c}{ Coefficients $^{\mathrm{a}}$} & \\
Model & Unstandardized & Standardized \\
& Coefficients & Coefficients \\
& B $\quad$ Std. Error & Beta
\end{tabular}




\section{AkMen}

$1 \quad$ (Constant)

Teknologi Informasi

Pemahaman Sistem Informasi

Akuntansi

a. Dependent Variable: Kinerja Pengelola Keuangan Pemerintah

Source: Data diolah (2020)

Berdasarkan tabel 10 hasil tersebut apabila ditulis dalam bentuk standardisasi dari persamaan regresinya adalah sebagai berikut :

$$
\mathrm{Y}=-0.378+0,425 \mathrm{X} 1+0,678 \mathrm{X} 2+0.600 \mathrm{e}
$$

Model persamaan persamaan regresi Unstandardized Coefficients, yang berarti: Konstanta -0.378 berarti Kinerja Pengelola Keuangan Pemerintah akan tetap konstan menurun sebesar -0.378 jika tidak ada pengaruh dari variable Teknologi Informasi $\left(\mathrm{X}_{1}\right)$, dan Pemahaman Sistem Informasi Akuntansi $\left(X_{2}\right)$; Koefisien regresi $X_{1}$ sebesar 0,425 berarti bahwa Teknologi Informasi $\left(\mathrm{X}_{1}\right)$ berpengaruh positif terhadap Kinerja Pengelola Keuangan Pemerintah (Y) yang menunjukkan bahwa dengan adanya Teknologi Informasi Pegawai, maka terjadi peningkataan pada Kinerja Pengelola Keuangan Pemerintah sebesar 42.5\%; Koefisien regresi $\mathrm{X}_{2}$ sebesar 0,678 berarti bahwa Pemahaman Sistem Informasi Akuntansi $\left(\mathrm{X}_{2}\right)$ berpengaruh positif terhadap Kinerja Pengelola Keuangan Pemerintah (Y) yang menunjukkan bahwa dengan adanya Pemahaman Sistem Informasi Akuntansi maka akan terjadi peningkatan Kinerja Pengelola Keuangan Pemerintah sebesar 67.8\%; Faktor variabel lainnya (Error) sebesar 0.600 diperoleh dari nilai $\mathrm{R}$ square $\mathrm{SQRT}(1-0.640)=0.600$ yang berarti bahwa variabel yang tidak diteliti dalam penelitian ini dapat meningkatkan Kinerja Pengelola Keuangan Pemerintah sebesar 60\%.

Tabel 11. Hasil Perhitungan uji-t Coefficients $^{\mathbf{a}}$

\begin{tabular}{llll}
\hline \multicolumn{2}{c}{ Coefficients } & $\mathrm{t}$ & Sig. \\
& & & \\
\hline 1 & (Constant) & & \\
& Teknologi Informasi & 3.960 & .000 \\
& Pemahaman Sistem Informasi Akuntansi & 6.323 & .000 \\
\hline
\end{tabular}

a. Dependent Variable: Kinerja Pengelola Keuangan Pemerintah Source: Data diolah (2020)

Berdasarkan tabel 11, pengujian dengan membandingkan nilai thitung > ttabel sebesar 2,008 (nilai ini diperoleh dari MsExcel $=\operatorname{TINV}(5 \%, 51)$ lalu enter) dan nilai signifikan $<0,05$ maka hipotesis diterima. Teknologi Informasi $\left(\mathrm{X}_{1}\right)$ dengan Nilai thitung $(3.960)>$ ttabel $(2,008)$ serta nilai signifikannya $(0,000)<(0,05)$ sehingga terbukti bahwa varibel Teknologi Informasi berpengaruh positif dan signifikan terhadap Kinerja Pengelola Keuangan Pemerintah, maka pada tingkat kekeliruan 5\% dinyatakan untuk hipotesis pertama bahwa $\mathrm{H}_{1}$ diterima. Pemahaman Sistem Informasi Akuntansi (X2) dengan Nilai thitung $(6.323)>$ ttabel $(2,008)$ serta nilai signifikannya $(0,000)<$ $(0,05)$ terbukti bahwa varibel Pemahaman Sistem Informasi Akuntansi berpengaruh positif dan signifikan terhadap Kinerja Pengelola Keuangan Pemerintah, maka pada tingkat kekeliruan 5\% dinyatakan untuk hipotesis kedua bahwa $\mathrm{H}_{2}$ diterima.

Tabel 12. Hasil Perhitungan Uji-f 
Hal. 55 - 70

e-ISSN : 2621-4377 \& p-ISSN : 1829-8524

Hbmepage: https//e-jurnal.stiendbel-indonesiaacid/indexphp/akmen

\begin{tabular}{llrrrrc}
\hline \multicolumn{7}{c}{ ANOVA $^{\mathrm{a}}$} \\
& Model & Sum of Squares & df & Mean Square & \multicolumn{1}{c}{ F } & Sig. \\
\hline 1 & Regression & 12.551 & 2 & 6.276 & 45.368 & $.000^{\mathrm{b}}$ \\
& Residual & 7.055 & 51 & .138 & & \\
& Total & 19.606 & 53 & & & \\
\hline
\end{tabular}

a. Dependent Variable: Kinerja Pengelola Keuangan Pemerintah

b. Predictors: (Constant), Pemahaman Sistem Informasi Akuntansi, Teknologi Informasi Source: Data diolah (2020)

Dari hasil analisis regresi dapat diketahui bahwa secara Bersama-sama variabel independen berpengaruh signifikan terhadap variabel dependen. Hal ini dapat dibuktikan dari nilai fhitung sebesar $45.368>$ ftabel sebesar 3.179 (nilai ini diperoleh dari MsExcel $=$ FINV $(5 \%, 2,51)$ lalu enter) dengan nilai signifikasi (sig) sebesar $(0.000)$ $<(0,05)$ maka pada tingkat kepercayaan $95 \%$ dapat dikatakan hipotesis ketiga diterima yang berarti Teknologi Informasi dan Pemahaman Sistem Informasi Akuntansi berpengaruh positif dan signifikan secara simultan terhadap Kinerja Pengelola Keuangan Pemerintah.

Tabel 13. Hasil uji koefisien determinasi Model Summary ${ }^{\mathrm{b}}$

\begin{tabular}{|c|c|c|c|}
\hline Model & $\mathrm{R}$ & R Square & Adjusted R Square \\
\hline 1 & $.800^{\mathrm{a}}$ & .640 & .626 \\
\hline
\end{tabular}

Berdasarkan tabel 13, diketahui R Square sebesar 0,640. Berdasarkan nilai R Square (R2) ini dapat dikatakan bahwa sebesar 64\% variasi Kinerja Pengelola Keuangan Pemerintah yang dapat dijelaskan oleh Teknologi Informasi dan Pemahaman Sistem Informasi Akuntansi sedangkan variasi Kinerja Pengelola Keuangan Pemerintah yang tidak dapat dijelaskan oleh Teknologi Informasi dan Pemahaman Sistem Informasi Akuntansi tetapi bisa dijelaskan oleh fakta - fakta lain yang tidak diamati oleh penelitian ini adalah sebesar 36\% (100\% - 64\%). sebagai contoh yaitu fakta lain yang tidak diamati oleh penelitian ini yang menunjang Kinerja Pengelola Keuangan Pemerintah adalah kapasitas sumber daya manusia, pengelolaan Keuangan daerah, pengawasan internal, dan komitmen organisasi.

\section{PEMBAHASAN}

Hasil pengujian hiptesis pertama menunjukkan bahwa teknologi informasi berpengaruh positif dan signifikan terhadap Kinerja Pengelola Keuangan Pemerintah. Hasil penelitian ini dibuktikan dari tanggapan responden terhadap variabel Teknologi Informasi Pegawai dimana para pegawai menganggap teknologi menambah pengetahuan dan dapat meningkatkan kinerja pegawai. Selanjutnya, tanggapan responden terhadap variabel Kinerja Pengelola Keuangan Pemerintah yang menunjukkan bahwa para pegawai mampu menyelesaikan laporan keuangan tepat waktu dan sesuai dengan batas periode pelaporan yaitu per 31 desember tiap tahunnya. Hal ini menunjukkan bahwa semakin meningkatnya Teknologi Informasi maka dapat 
meningkatkan Kinerja Pengelola Keuangan Pemerintah. Menurut Wahyudi, (2010), pemanfaatan teknologi informasi yang baik secara garis besar dapat memberikan dampak yang positif bagi pengelolaan keuangan pemerintah daerah. Selain itu, Wardani et al., (2017) menyatakan bahwa Teknologi informasi mempunyai kelebihan dalam keakuratan dan ketepatan hasil operasi datanya. Pemanfaatan teknologi informasi juga akan mengurangi kesalahan yang terjadi, baik yang disengaja maupun tidak disengaja. Teknologi informasi bagi kalangan dewasa ini menjadi hal yang sangat penting karena sudah banyak organisasi yang menerapkan teknologi informasi untuk mendukung kegiatan organisasi. Penerapan teknologi informasi pada tiap perusahaan atau organisasi tentunya memiliki tujuan yang berbeda karena penerapan teknologi informasi pada suatu organisasi adalah untuk mendukung kepentingan usahanya. Sehingga untuk mengatasi keterlambatan penyetoran dokumen Rencana Kerja (Renja) dan Laporan Akuntabilitas Kinerja Instansi Pemerintah (LAKIP) tahun 2018 ke Bappeda Kota Makassar, dibutuhkan berbagai teknologi yang dapat membantu serta pegawai yang mempu beradaptasi dengan cepat terhadap teknologi baru yang diterapkan pemerintah untuk mempercepat proses penyetoran.

Hasil penelitian ini didukung pandangan menurut Williams \& Sawyer, (2011) teknologi informasi merupakan suatu teknologi yang menggabungkan komputasi (komputer) dengan jalur komunikasiyang mempunyai kecepatan tinggimembawa data, suara, dan video. Hal yang sama juga di ungkapkan oleh Prasajo, (2011) teknologi informasi diartikan sebagai ilmu pengetahuan dalam bidang informasi yang berbasis komputer dan perkembanganya sangat pesat. Selanjutnya, Uno \& Lamatenggo, (2011) juga mengemukakan teknologi informasi adalah suatu teknologi yang digunakan untuk mengolah data. Sementara itu, hasil penelitian ini sejalan dengan penelitian yang dilakukan oleh Chintya, (2015), menyebutkan bahwa Teknologi Informasi berpengaruh positif terhadap Kinerja Pengelola Keuangan Pemerintah.

Hasil pengujian hipotesis kedua menunjukkan bahwa pemahaman sistem Informasi Akuntansi berpengaruh positif dan signifikan terhadap Kinerja Pengelola Keuangan Pemerintah. Hasil penelitian ini dibuktikan dari tanggapan responden terhadap variabel Pemahaman Sistem Informasi Akuntansi yang menunjukkan bahwa berkat Pemahaman Sistem Informasi Akuntansi pegawai dapat Fokus melaksanakan tugas yang berhubungan dengan akuntansi. Selanjutnya, tanggapan responden terhadap variabel Kinerja Pengelola Keuangan Pemerintah dimana para pegawai mampu menyelesaikan laporan keuangan tepat waktu dan sesuai dengan batas periode pelaporan. Hal tersebut menunjukkan apabila pegawai paham dengan Sistem Informasi Akuntansi dengan fokus melaksanakan tugas yang berhubungan dengan akuntansi, maka dapat membuat peningkatan pada Kinerja Pengelola Keuangan Pemerintah dengan Pegawai mampu menyelesaikan laporan keuangan tepat waktu dan sesuai dengan batas periode pelaporan yaitu per 31 desember tiap tahunnya. Dengan meningkatnya Pemahaman Sistem Informasi Akuntansi maka dapat meningkatkan Kinerja Pengelola Keuangan Pemerintah. Oleh karena itu, untuk mempercepat proses penyetoran, dibutuhkan pemahaman sistem informasi akuntansi yang dimana dapat membatu karyawan dalam memahami berbagai aturan yang ditetapkan pemerintah agar menghindari kesahalan dalam proses pembuatan data Rencana Kerja (Renja) dan Laporan Akuntabilitas Kinerja Instansi Pemerintah (LAKIP) serta pemahaman ini dapat mempecepat proses penyetoran. Menurut Pemendagri No.21 Tahun 2011 tentang 
Pedoman Pengelolaan Keuangan Daerah, sistem informasi akuntansi keuangan pemerintah daerah meliputi serangkaian prosedur mulai dari proses pengumpulan data, pencatatan, pengihtisaran, sampai dengan pelaporan keuangan dalam rangka pertanggungjawaban pelaksanaan APBN yang dapat dilakukan secara manual atau menggunakan aplikasi komputer. Keberadaan sebuah sistem akuntansi menjadi sangat penting karena fungsinya dalam menetukan kualitas (kinerja) informasi pada laporan keuangan.

Hasil penelitian ini didukung oleh Susanto, (2017) yang menyatakan bahwa sistem informasi akuntansi adalah kumpulan tau grup dari sub sistem/ bagian/ komponen apapun baik fisik atau non fisik yang saling berhubungan satu sama lain dan bekerja sama secara harmonis untuk mengolah data transaksi yang berkaitan dengan masalah keuangan menjadi informasi keuangan. Selain itu, menurut Romney \& Steinbart, (2014) sistem informasi akuntansi adalah suatu sistem yang mengumpulkan, mencatat, menyimpan dan mengolah data untuk menghasilkan informasi bagi pengambilan keputusan. Hasil penelitian ini juga sejalan dengan penelitian yang dilakukan oleh Erawati \& Abdulhadi, (2018) dari penelitiannya menyebutkan bahwa Pemahaman Sistem Informasi Akuntansi berpengaruh positif terhadap Kinerja Pengelola Keuangan Pemerintah.

Secara simultan, variabel teknologi informasi dan pemahaman sistem informasi Akuntansi berpengaruh positif dan signifikan secara simultan terhadap Kinerja Pengelola Keuangan Pemerintah. Pada variabel Teknologi Informasi, para pegawai menganggap teknologi menambah pengetahuan dan dapat meningkatkan kinerja pegawai. Selanjutnya, berdasarkan tanggapan responden, variabel Pemahaman Sistem Informasi Akuntansi menunjukkan bahwa Pemahaman Sistem Informasi Akuntansi pegawai dapat meningkatkan fokus pegawai dalam melaksanakan tugas yang berhubungan dengan akuntansi. Pada variabel Kinerja Pengelola Keuangan Pemerintah, tanggapan responden menunjukkan bahwa Pegawai mampu menyelesaikan laporan keuangan tepat waktu dan sesuai dengan batas periode pelaporan. Semakin meningkatnya Teknologi Informasi dan Pemahaman Sistem Informasi Akuntansi maka Kinerja Pengelola Keuangan Pemerintah akan meningkat. Menurut Kasmir, (2013), Kinerja Pengelolaan Keuangan adalah laporan yang menunjukkan kondisi keuangan perusahaan pada saat ini atau dalam suatu periode tertentu. Selain itu, Sari \& Pamono, (2013) menyatakan bahwa Informasi yang berkualitas tentunya diperoleh dari adanya sistem informasi yang dirancang dengan baik. Kehadiran teknologi, terutama dalam dunia bisnis, banyak dimanfaatkan oleh para pelaku bisnis untuk memperoleh keuntungan baik yang bersifat material maupun non-material, seperti efisiensi dalam kegiatan organisasi bisnis, pengendalian internal yang baik dan lain sebagainya. Salah satu teknologi yang banyak digunakan dalam dunia bisnis adalah teknologi informasi yang dimanfaatkan terutama dalam sistem informasi, maka berdasarkan pernyataan tersebut, dibutuhkan adanya teknologi informasi dan Pemahaman Sistem Informasi Akuntansi agar dapat meningkatkan Kinerja Pengelolaan Keuangan Pemerintah.

Hasil penenlitian ini sejalan dengan penelitian yang dilakukan oleh Chintya, (2015) membuktikan dalam hasil penelitiannya bahwa Pemanfaatan Teknologi Informasi memiliki pengaruh positif terhadap Kinerja Instansi Pemerintah. Berikutnya hal yang sama dibuktikan dalam hasil penelitian yang dilakukan oleh Liza et al., (2017) yang membuktikan bahwa teknologi informasi berpengaruh terhadap kualitas laporan keuangan. 


\section{KESIMPULAN}

Berdasarkan hasil penelitian, Teknologi Informasi berpengaruh positif dan signifikan terhadap Kinerja Pengelola Keuangan Pemerintah yang menunjukkan bahwa dengan meningkatnya Teknologi Informasi maka dapat meningkatkan Kinerja Pengelola Keuangan Pemerintah. Sementara itu, Pemahaman Sistem Informasi Akuntansi berpengaruh positif dan signifikan terhadap Kinerja Pengelola Keuangan Pemerintah yang menunjukkan bahwa dengan meningkatnya Pemahaman Sistem Informasi Akuntansi maka dapat meningkatkan Kinerja Pengelola Keuangan Pemerintah. Adapun Teknologi Informasi dan Pemahaman Sistem Informasi Akuntansi berpengaruh positif dan signifikan secara simultan terhadap Kinerja Pengelola Keuangan Pemerintah yang menunjukkan bahwa seiring meningkatnya Teknologi Informasi dan Pemahaman Sistem Informasi, maka Kinerja Pengelola Keuangan Pemerintah juga akan ikut berkembang.

Masih banyak factor lain yang menunjang peningkatan kinerja pengelolaan keuangan, seperti kapasitas sumber daya manusia, pengawasan internal, dan komitmen organisasi. Oleh karena itu, peneliti selanjutnya diharapkan lebih mengembangkan pengetahuan akuntansi terkait akuntansi sector publik yang erat kaitannya dengan topik penelitian agar variabel yang digunakan dapat lebih meluas lagi.

\section{DAFTAR PUSTAKA}

Chintya, I. (2015). Pengaruh Pemanfaataan Teknologi Informasi dan Sistem Pengendalian Intern Pemerintah terhadap Kinerja Instansi Pemerintah Di Kota Solok (Studi pada Skpd Kota Solok). Jurnal Ekonomi Dan Bisnis.

Diana, David, \& Ventje. (2017). Pengaruh Implementasi Sistem Akuntansi, Pengelolaan Keuangan Daerah dan Pengawasan Internal terhadap Kinerja Pemerintah Kota Kotamobagu. Jurnal Ekonomi Dan Bisnis.

Erawati, T., \& Abdulhadi, F. (2018). Pengaruh Pemahaman Sistem Akuntansi Keuangan Daerah, Kapasitas Sumber Daya Manusia dan Pemanfaatan Teknologi Informasi terhadap Kualitas Informasi Laporan Keuangan Pemerintah Daerah (Studi Kasus pada Pemerintah Daerah Kota Yogyakarta). Jurnal Ekonomi Dan Bisnis.

Kasmir. (2013). Analisis Laporan Keuangan (1st ed.). Rajawali Pers.

Krismiaji. (2015). Sistem Informasi Akuntansi (4th ed.). UPP STIM YKPN.

Lannai, D., \& Amin, A. (2020). Factors Affect Budget Absorption in Government Institutions of South Sulawesi. ATESTASI: Jurnal Ilmiah Akuntansi, 3(2), 113-119.

Liza, Yossi, \& Zuraida. (2017). Pengaruh Sistem Pengendalian Intern, Teknologi Informasi, Kualitas Sumber Daya Manusia dan Komitmen Organisasi terhadap Kualitas Laporan Keuangan (Studi pada Satker Di Lingkungan Kementerian Agama Kabupaten Aceh Utara). Jurnal Ekonomi Dan Bisnis.

Mahsun, M. (2013). Pengukuran Kinerja Sektor Publik. BPFE.

Mukmin, D., \& Abdullah, S. (2015). Pengaruh Pemahaman Sistem Akuntansi 
Keuangan Daerah, Penatausahaan Keuangan Daerah dan Pengelolaan Keuangan terhadap Kinerja SKPD pada Pemerintahan Kabupaten Aceh Tenggara. 4(2).

Rafiudin, I. (2013). Perbedaan Teknologi Informasi dengan Sistem Informasi. Iswanti Rafiudin. http://iswanticha.blogspot.com/2013/04/perbedaan-teknologi-informasidengan.html

Rahim, S., Ahmad, H., Muslim, M., \& Nursadirah, A. (2020). Disclosure of Local Government Financial Statements in South Sulawesi. In Brawijaya International Conference on Multidisciplinary Sciences and Technology (BICMST 2020) (pp. 16). Atlantis Press.

Romney, \& Steinbart. (2014). Sistem Informasi Akuntansi. Salemba Empat.

Sari, M., \& Pamono, Y. . (2013). Pengaruh Pemanfaatan Teknologi terhadap Sistem Informasi Akuntansi. Jurnal Ilmu \& Riset Akuntansi, 2(8), 1-14.

Susanto, A. (2017). Sistem Informasi Akuntansi : Pemahaman Konep secara Terpadu. Linggar Jaya.

Sutarman. (2012). Pengantar Teknologi Informasi. Bumi Aksara.

Uno, H. B., \& Lamatenggo, N. (2011). Teknologi Komunikasi dan Informasi Pembelajaran. Bumi Aksara.

Yusuf, M., \& Kanji, L. (2020). Effect of Internal Audit and Accounting Information System on the Effectiveness of Internal Control. ATESTASI: Jurnal Ilmiah Akuntansi, 3(2), 120-125.

Wahyu. (2016). Pengaruh Pertumbuhan Ekonomi, Pendapatan Asli Daerah, Dana Alokasi Umum, Dana Alokasi Khusus, dan Sisa Lebih Pembiayaan Anggaran terhadap Anggaran Belanja Modal. Jurnal Ekonomi Dan Bisnis Universitas Muria Kudus.

Wahyudi, J. (2010). Pengaruh Sumber Daya Manusia dan Pemanfaatan Teknologi Informasi terhadap Keterandalan dan Ketepatwaktuan Pelaporan Keuangan Pemerintah Daerah dengan Pengendalian Internal Akuntansi sebagai Intervening. Ikip Mataram.

Wardani, Kusuma, D., \& Andriyani, I. (2017). Pengaruh Kualitas Sumber Daya Manusia, Pemanfaatan Teknologi Informasi, dan Sistem Pengendalian Intern terhadap Keandalan Pelaporan Keuangan Pemerintahan Desa Di Kabupaten Klaten. Jurnal Akuntansi, 5(2).

Williams, B. K., \& Sawyer, S. . (2011). Using Information Technology: Apractical Introduction to Computers and Communications (9th ed.). Mcgraw-Hill.

Zelmiyanti, R. (2016). Pendekatan Teori Keagenan pada Kinerja Keuangan Daerah dan Belanja Modal (Studi pada Provinsi Di Indonesia). JRAK, 7(1). 